\title{
THE TREATMENT FOR FEDERAL INCOME TAX PURPOSES OF ERRORS IN THE DEDUCTION OF OTHER TAXES
}

\section{Robert C. BRown †}

The problem considered in this paper is the method of correcting errors in the deduction of taxes in computing taxable net income for federal income tax purposes. Obviously, similar problems will be presented in the administration of state net income taxes; but a consideration of the federal problem and the authorities thereon will be sufficient for this purpose also.

It must be noted, before going any further, that certain taxes which were deductible under some previous federal laws are no longer so. For example, no estate or inheritance taxes, whether federal or state, are now deductible in computing net income, though they were deductible under the acts previous to I934. Authorities with regard to taxes not now deductible will be cited, however, as they are, of course, still important in connection with the treatment of taxes which may still be deducted.

More specifically, the problem has the following ramifications: First, suppose that a totally unconstitutional or otherwise illegal tax has been exacted from a taxpayer and deducted by him for federal income tax purposes in the year when paid or accrued. In a subsequent year such illegal tax is refunded to the taxpayer by the state or federal authority to whom it has been paid. Should the taxpayer treat this refund as additional income for the year in which it is made, or should he pay an additional tax for the year in which he erroneously, though in good faith, made this deduction?

Very similar is the problem with respect to a good faith over-payment of a tax legally imposed. The taxpayer will have deducted too much for the year in which he pays and will presumptively receive a refund of the excess in a subsequent year. Here, too, the question is whether the refund will constitute taxable income in such subsequent year, or whether it will simply go to reduce the deduction taken in the previous year, thereby increasing the income tax liability for that year.

The problem may, of course, come up the other way around. The taxpayer may fail to deduct at all a tax which was properly payable or was at least a proper accrual for a previous year. Or he may deduct the amount which he pays or accrues on account of such tax; but such amount may turn

$\dagger$ A. B., 19I4, Wesleyan University; LL. B., I9I7, S. J.D., I930, Harvard University; author of State Taxation of Interstate Commerce, and Federal and State Taxation in Intergovermuental Relations-I930-I932 (1933) 8I U. OF PA. L. Rev. 247; The Time for Taking Deductions for Losses and Bad Debts for Income Tax Purposes (I935) 84 U. of PA. L. REv. $4 \mathrm{I}$, and of numerous other articles in various legal periodicals; Professor of Law, Indiana University. 
out to be less than that ultimately determined to be due. In either case he will have to pay an additional assessment in a subsequent year. Here the basic problem is similar. Is the additional payment a proper deduction for the year in which it is made, or must the taxpayer, by amended return or otherwise, claim it as an additional deduction for the year in which it should have been paid or accrued and thereby reduce his income tax liability for that year?

The practical importance of this problem is easily seen. Even if the rates of taxation remain the same, it might make a considerable difference because of varying surtax brackets into which the taxpayer might happen to fall. For instance, his income in the previous year might be larger than in the year in which a refund is made so that he would have to pay a surtax on it in the higher tax brackets; or, of course, it might work in the opposite way. It would seem, however, that the problem can well be considered without reference to this matter. Whether it works for the benefit of the taxpayer or of the government, the taxpayer should from this standpoint be compelled to go back to the previous year and make the correction; for he is in fact correcting a mistake and thereby paying the precise amount of tax which was legally due in that year.

There are, however, two circumstances which throw some difficulties upon the workability of this theoretically correct solution of the problem. In the first place, the actual rates of tax vary from act to act, recently almost from year to year. During recent years the rates of tax have tended to go up, so that to force (or permit) the taxpayer to correct an error resulting in underpayment of income tax in a previous year will generally be to his advantage. However, it is at least conceivable that this tendency may sometimes be reversed and that tax rates will go down, in which case the retroactive correction of such an error will be advantageous to the government. If the taxpayer's error is the failure to make a large enough tax deduction, thus improperly increasing his apparent income tax liability, the relative advantages to him and to the government of the two possible methods of correcting the mistake are, of course, exactly reversed.

More important still is the problem of the statute of limitations as affecting the income tax. If the correction of the error in a previous year results in additional income tax liability for that year, the government may often be precluded from collecting such liability, as normally the taxpayer will have acted in good faith. If, on the other hand, the correction results in a refund of federal income tax being due to the taxpayer by reason of his failure to deduct a sufficient amount of the other sort of tax, the taxpayer will quite often be precluded by the running of the statute of limitations from recovering the overpaid income tax from the government. It is evident, therefore, 
that the operation of the statute of limitations is very likely to lead to an unjust result either to the government or to the taxpayer, if the latter is allowed or compelled to adjust his taxable income as of the year when the error was made.

In the light of these considerations, it is apparent that the more practical, and frequently the more just, solution is to let the error of the previous year stand. This means that any refund of a tax previously deducted will constitute taxable income when received by the taxpayer and that any additional taxes which he is compelled to pay will be a deduction for him in the year when so paid. While there is a possibility of actual error with respect to the surtax rates in these different years, this is usually not a serious matter. Furthermore, if this solution is made obligatory upon both the taxpayer and the government (as it should be if it is applied on either side) one is about as likely to benefit from it as the other. The same may be said with reference to the variation of rates in the different acts. And, in a sense, the same is true with reference to the effect of the statute of limitations ; but here the possible injustices of requiring retroactive correction of the error do not in any realistic sense cancel each other. If the taxpayer is permitted to correct the error of the previous year, as to which the statute of limitations has run, and such correction results in additional income tax liability for that year, the government is deprived of the possibility of collecting an income tax which was legally due, the taxpayer thus being benefited at the expense of the government by his own mistake. If, on the contrary, the correction of the error shows that the taxpayer has overpaid his federal income tax for the previous year, the statute of limitations will preclude his obtaining a refund, and the result is that the government keeps an amount to which it was not legally entitled. It may be urged that there is no real injustice in this, since it was the taxpayer's own mistake. However, payments of taxes are not ordinarily made except in pursuance of compulsion. Even if the tax is on its face paid voluntarily, it is evident that this is done only because of the knowledge of the taxpayer that such payment can and almost certainly will be coerced. The language of Mr. Justice Stone in United States v. S. S. White Dental Mfg. Co., ${ }^{1}$ a case involving governmental action, though by way of confiscation rather than taxation, is certainly somewhat apposite:

"It would require a high degree of optimism to discern in the seizure of enemy property by the German government in IgI8 more than a remote hope of ultimate salvage from the wreck of the war. The Taxing Act does not require the taxpayer to be an incorrigible optimist." 2

Perhaps this reasoning is not wholly applicable when the taxpayer has underpaid the deductible tax and, therefore, made an inadequate deduction

I. 274 U. S. 398 (1927). But cf. Lucas v. American Code Co., 280 U. S. 445 (1930).

2. Id. at 403 . 
for income tax purposes; but, as already shown, under such circumstances compelling the taxpayer to make the correction in the previous year will often unjustly penalize him through the operation of the statute of limitations. It would seem, therefore, that if the problem of losses should be treated on a practical basis, ${ }^{3}$ the same result should be true as to any error in the deduction of taxes, at least if the taxpayer acted in good faith and with reasonable care, as would usually be true.

But this is certainly not the way that the Bureau of Internal Revenue, the Board of Tax Appeals, and the courts handle the matter. It would appear that these authorities not merely tend toward the rule that the correction must be made in the previous year, but they avowedly state that this rule is invariable. It is frequently said that under no circumstances will the error of the previous year be allowed to stand and the correction be made in the year of adjustment, either by taxing as income for that year a refund received by the taxpayer or allowing as a deduction in that year the additional tax paid by him. ${ }^{4}$ While, as will presently appear, the actual decisions do not seem to adhere to this rule quite as rigidly as this language would suggest, yet most of them do adhere to the doctrinal compulsion of retroactive correction of the mistake rather than the more practical method here suggested.

The authorities seem unanimous this way with reference to the computation of invested capital for federal excess profits taxes imposed under the Revenue Acts of 1917,1918 , and I92I. It seems to be universally held that what is ultimately determined to be the correct amount of other taxes payable by a taxpayer subject to excess profits tax must be deducted in computing its invested capital, irrespective of errors made by the taxpayer in its books or in the actual payment of the tax. ${ }^{5}$ However, these rulings were probably justified. In the first place, the statutory definition of invested capital is distinctly conceptual, bearing only a somewhat attenuated relation to the amount actually used in the business. ${ }^{6}$ Furthermore, the practical difficulties as to varying rates and the effect of the statute of limitations, which are involved in the income tax problem, are not present in the matter of excess profits tax, at least to any such degree. This rather theoretical basis for applying tax and other deductions from invested capital may, therefore, be correct; but it constitutes no necessary precedent for similar treatment of such deductions for income tax purposes.

3. See Brown, The Tine for Taking Deductions for Losses and Bad Debts for Income Tax Purposes (1935) 84 U. of PA. L. REV. 4I.

4. E. g., I. T. 2578, X-I CuM. Bull. II9 (I93I).

5. American Cigar Co., 2I B. T. A. 464 (I930), aff'd, 66 F. (2d) 425 (C. C. A. 2 d, 1933), cert. denied, 290 U. S. 699 (1933). Conversely, taxes illegally exacted from a taxpayer should be added to its invested capital. United States Trust Co. of N. Y., I3 B. T. A. I074 (I928); Diamond Alkali Co. v. Heiner, 39 F. (2d) 645 (W. D. Pa. 1930).

6. La Belle Iron Works v. United States, 256 U. S. 377 (I921). 
Passing to the actual decisions with regard to income taxes, it seems to be the settled rule that unconstitutional or otherwise illegal taxes are not deductible, and, if already deducted, the error must be corrected for the year in which the improper deduction was made. ${ }^{7}$ The Bureau of Internal Revenue has conceded that it would be easier to allow the deduction to stand and treat the refund as additional income when received; but it insists that this convenient method is not in accordance with law and therefore can not be permitted. 8

The same rule is applied if the tax is itself valid but has been improperly applied so as to exact a payment not legally due from the particular taxpayer. ${ }^{9}$ As will be pointed out hereafter, the Bureau seems not always to adhere to this doctrine when the application of the statute of limitations will be unfavorable to the government, but it is certainly the usual rule. And the same result is reached when a tax is legally due and payable but has through some error been overpaid. ${ }^{10}$ The amount of tax so overpaid is not deductible for the year in which paid or accrued, and the error must be retroactively corrected in that year.

The leading authority for this general position is undoubtedly Inland Products Co. v. Blair. ${ }^{11}$ Here the plaintiff paid a federal beverage tax in I9I9 and I920, which was illegally exacted because of erroneous regulations. It was conceded, however, that, since the tax had been voluntarily paid, the statutes gave no right to sue the government for its recovery, though in fact it had been later actually refunded. The taxpayer desired to have the deduction remain in the years when the tax was paid, as the rates were higher in those years. The court in denying this claim lays much stress on this very fact. As already pointed out, this argument would probably work to the disadvantage of the government at the present time, when tax rates are increasing. But the following language of the court is particularly important:

"The taxpayer's position is that, as the amount erroneously paid was not recoverable as a matter of right, it should be treated as a loss occurring during the year in which paid, and that the refund should be treated as income of the year in which received. In support thereof it relies particularly upon U. S. v. S. S. White Dental Mfg. Co., 274 U. S. 398 , in which it was held that the loss of a stockholder in a German corporation arising from the seizure of its property by the German government was deductible in the year in which the loss was sustained, even

7. Philip C. Brown, ro B. T. A. II22 (1928) ; Lehigh Valley Coal Sales Co., r5 B. T. A. I40r (I929) ; E. L. Bruce Co., I9 B. T. A. 777 (I930); see 3 PaUl and Mertens, LAW of FEDERAI InCOME TAXation (I934) § 25.05.

8. I. T. 2578, X-I Cun. Butc. II9 (I93I).

9. O. D. 74I, 3 Cum. Bull. II5 (I920); Joseph V. Horn, 23 B. T. A. II3I (I93I). But cf. Houbigant, Inc., 3r B. T. A. 954 (r934).

Io. Leach v. Comm'r, 50 F. (2d) 37I (C. C. A. Ist, 193I), aff'g, 16 B. T. A. 78I (I929).

II. 3I F. (2d) 867 (C. C. A. 4th, I929), aff'g, Io B. T. A. 235 (I928). 
though in a subsequent year the German government bound itself to repay and an award was made by the Mixed Claims Commission which might result in recovery. But money erroneously paid to the government as taxes is not in any true sense a loss, and is not to be treated as such. Even though payments voluntarily made may not be recoverable at law, the fairness of the government in such matters can be relied upon, and experience has demonstrated, as in this case, that the taxpayer, who by mistake has paid too much, can depend on the government's reimbursing him, whether he has the right to sue for a refund or not. And certainly such erroneous payment is not a loss within the meaning of Section 234 (a) (4) of the Revenue Act [citing cases]. Furthermore, in this case we are dealing, not with losses and recoupment of losses in the ordinary business transactions of the corporation, but with the correction of a mistake between the government and the taxpayer, and the principles to be applied are those applicable to the correction of such mistakes. Such cases as that of U. S. v. S. S. White Dental Mfg. Co., therefore, are manifestly not in point." 12

It is submitted that United States v. S. S. White Dental Mfg. Co., ${ }^{13}$ which has been already referred to, is not very effectively distinguished. The court's idea that the federal government can be depended upon to pay back all of its obligations, even though it is not subject to suit at all, is, to say the least, somewhat doubtfu1. ${ }^{14}$ The average taxpayer who has paid money to the federal government which he has no definite right to recover (or even sometimes if he has) is not in a very hopeful position for avoiding the loss. The practical and sensible test applied in the White case would, therefore, indicate an opposite result in the Inland case.

Nor has the Board of Tax Appeals been wholly deaf to this contention. In E. L. Bruce Co., ${ }^{15}$ the Board had under consideration the deductibility of an amount paid under an Arkansas corporation tax law which was later declared unconstitutional. The law was declared unconstitutional only in relation to foreign corporations, and the taxpayer was a domestic corporation. Since the taxpayer had no right to sue the state, there was no legal power to obtain a refund; and it was at least arguable whether there was any equitable right. At any rate, the Board pointed out that no refund had been made or was likely to be made. It therefore held that though the tax was not strictly deductible as a tax (because illegal), yet it was deductible as a loss. ${ }^{16}$

I2. Id. at 868-9.

I3. 274 U. S. 398 (I927).

I4. Cf. Perry v. United States, 294 U. S. 330 (1935).

I5. I9 B. T. A. 777 (1930); cf. Houbigant, Inc., 3I B. T. A. 954 (1934).

I6. "In the case at bar we have no evidence that a refund has been made and under the Constitution of Arkansas, Article V, Sec. 20, the State of Arkansas may not be made defendant in a suit in any of her courts. The further fact exists that the statute in question was not declared unconstitutional because of any defect with respect to domestic corporations, such as petitioner's predecessor, but rather because of an improper attempt to tax foreign corporations, and since the provisions of the act were not severable as between domestic and foreign corporations, it was declared unconstitutional in all respects. Of course, refund might have 
It is submitted that the Board takes the correct view, in substantially allowing the deduction of the tax, though under the guise of a "loss". A tax is not a loss, but it often feels like it to the taxpayer. At any, rate, this tax was lost in fact; regardless of the legal situation, the money was gone, and the deduction was properly allowed.

In this matter, therefore, the authorities nearly unanimously take the purely theoretical test. The erroneous deduction must be corrected in the previous year, thus resulting in additional federal income tax for that year; and it follows that refunds made in a subsequent year are not taxable income for the year of such refunds. ${ }^{17}$

The next problem arises when the taxpayer has utterly failed to deduct a tax legally due and which would be a proper deduction for income tax purposes. The question is whether such taxes can be deducted when the taxpayer is later compelled to pay them.

Where the taxpayer properly reported on the cash basis, it seems that this is allowable. He is entitled to deduct such a tax when he pays it, irrespective of whether such payment is on time or not. ${ }^{18}$ But a taxpayer who keeps his books on the accrual basis (as most large taxpayers do) must deduct such a tax when it is a proper accrual. This in itself is a difficult problem. The question of what is a proper accrual is one rather of accounting than of law and is extremely difficult. The Board of Tax Appeals has used the following very lucid language to explain the lack of lucidity of the concept :

"A study of the multitude of decisions, treatises, and variously expressed views, and our experience in the consideration of many cases presented to this Board in which the word is either carefully or loosely used, disclose that the word 'accrue' is fraught with confusion because it expresses no certain concept. In law, it has long been used in respect of rights and obligations which are said to accrue when they become enforceable. In accounting, it may be variously used with equal authority to refer to a right or liability fixed in amount, or certain in all respects except amount, or to an apportionment of a right or liability

been had by appeal to the state legislature, but when we consider the circumstances under which the payment was made and the basis of the determination of unconstitutionality, we are unwilling to deny this amount as a deduction under such slight possibility that a refund may have been made. As the court said in United States v. White Dental Mfg. Co., 274 U. S. 398, when dealing with a loss under the corresponding provision of the I9I8 Act, what might ultimately be returned would be not as a matter of right but as a matter of grace, and, as the court said further in the same case, to look for anything would require one to be an "incorrigible optimist', which is not required by the taxing statutes. Certainly, from a practical, if not the strictest legal, standpoint (which was stated by the Supreme Court in Lucas v. American Code Co., 280 U. S. 445, as the test in determining when a loss is deductible), this petitioner sustained a loss or paid a necessary expense in I923 when it paid \$13,750 on account of an illegal exaction of what was then denominated taxes which it had no legal right to have returned to it and which has not been shown either to have been refunded or to have more than the merest possibility of ever being refunded." I9 B. T. A. at 780 .

I7. See authorities cited supra notes 9-II; Mim. 3958, XI-2 CUM. Bull. 33 (I932).

I8. Benjamin I. Powell, 26 B. T. A. 509 (1932). 
which runs hand in hand with a matter upon which it depends, or to a reserve in anticipation of an event, sometimes certain and sometimes uncertain. Other connotations will occur, but these are sufficient to indicate that there is little in common among the significations recognized. One thing is clear-that the word implies the exclusion of 'received' or 'paid', or a right or liability discharged. But short of this, what is meant when an item is accounted for as accrued depends upon the system of accounting in which it appears and the breadth of the accountant's concept." 19

Nevertheless, the authorities seem unanimous that a taxpayer who keeps his books on an accrual basis must deduct all expenses which are proper accruals in the year in which they become such, even though they are not yet due and payable. This applies to taxes. The leading case is United States $v$. Anderson. ${ }^{20}$ Here a taxpayer keeping books on an accrual basis was held to be obliged to deduct federal munitions taxes imposed for I9I 6 even though they were not due and payable until I9I7. The Court held quite correctly that such taxes were a proper expense in earning the income for I9I6 and were therefore deductible only in that year. It is to be noted that the amount of the munitions tax was quite easily computable and could be ascertained with almost perfect accuracy immediately after the close of the year; certainly, long before the federal income tax return was due. While in theory this last circumstance may be immaterial, yet it is clear that it influenced the Court very considerably.

It is submitted that while the Anderson case was correctly decided, it should not necessarily apply when the amount of the tax is entirely unascertainable during the year in question, or within a reasonable time thereafter. As has been said, the concept of accrual is basically one of accounting rather than law; and accountants will not recognize an accrual the amount of which is wholly unascertainable. In theory at least, a total failure to deduct a tax may be justified if either the taxpayer reasonably believes that no tax is due or its amount is not ascertainable with even fair accuracy.

But the authorities have applied the principle of the Anderson case with more logic than realism. The theory is that if a tax was ultimately an expense of earning the income for a particular year it is a proper accrual for that year and must accordingly be deducted by a taxpayer reporting on that basis in that year if at all. ${ }^{21}$ It makes no difference that the question of liability for the tax is in litigation ${ }^{22}$ or that the amount is entirely unascer-

I9. Ernest M. Bull, 7 B. T. A. 993, 995 (r927), aff'd, 6 F. Supp. I4I (Ct. Cl. 1934), rev'd on other grounds, 295 U. S. 247 (1935).

20. 269 U. S. 422 (I926) [approving the ruling in L. O. I059, 4 CUMr. BuLL. I47 (I92I), and I. T. 20II, III-I CuM. BuLl. 79 (1924)].

2I. Aluminum Castings Co. v. Routzahn, 282 U. S. 92 (1930); S. M. 2692, IV-r Cum. BuLl. Irg (I925).

22. Bartles-Scott Oil Co., 2 B. T. A. I6 (I925) ; 3 Paul and MERTens, op. cit. supra note $7, \S 25.48$. 
tainable. ${ }^{23}$ In Ernest M. Bull ${ }^{24}$ the Board of Tax Appeals, in holding that an estate tax accrues at the time of death and is therefore deductible only for that year, rather explicitly refused to consider the practical possibility of computing the amount of the tax as having any bearing on the problem. ${ }^{25}$

Naturally, however, such a taxpayer, unless barred by the statute of limitations, will be permitted to correct the error for the previous year by taking an additional deduction for such tax and thereby becoming entitled to an income tax refund. ${ }^{26}$ It has been held, however, that an amount offered to the government in compromise of a disputed liability for tax and penalties is not a proper deduction for income tax purposes for the year in which offered, unless the government accepts the offer during the same year. ${ }^{27}$

While the position of the Bureau and the courts in this matter seems somewhat rigid, perhaps no serious criticism can be made on this point. Undoubtedly, to permit a taxpayer to ignore entirely a tax which he knows must be an expense in some amount for a particular year and to deduct it later on is likely to be too lenient to him, to allow him to come close to playing fast and loose with the government. But when the same rule is applied where the taxpayer has attempted a deduction in good faith but has underestimated it so that he is compelled to pay an additional tax in a subsequent year, when perhaps an income tax refund for the previous year is already barred by the statute of limitations, the result seems thoroughly unjust. And yet the authorities say, and generally hold, that such an error must under all circumstances be corrected for the year in which it is made. ${ }^{28}$ That the additional assessments are for state income tax and therefore dependent upon largely unpredictable rulings of the administrative authorities is regarded as entirely immaterial. ${ }^{29}$ The reasoning back of such rulings is well shown by the opinion in Uncasville Mfg. Co. v. Comm'r, ${ }^{30}$ where the court had under consideration the problem of the deduction by the plaintiff of its Connecticut income tax. This tax for the year in question (I9I8) depended upon the federal income tax. After the close of the year the United States Commissioner of

23. Pictorial Review Co., 26 B. T. A. 472 (1932), rev'd on other grounds, 68 F. (2d) 766 (App. D. C. 1934).

24. 7 B. T. A. 993, 995 (I927), aff'd, 6 F. Supp. I4I (Ct. Cl. I934), rev'd on other grounds, 295 U. S. 247 (I935).

25. "The suggestion arises that it is difficult to determine the amount of estate tax within the period when the first income tax of the estate must be computed and the return audited. This might well give pause. But it is usually no more difficult than the computation of the munitions tax involved in the Yale \& Tozene case or that required by section 1207 of the Revenue Act of 1926 and the earlier regulations, and such difficulty as there may be is not sufficient to counterbalance the considerations already set forth." 7 B. T. A. at 999 .

26. Brinkerhoff-Faris Trust \& Savings Co., I4 B. T. A. 80I (I928).

27. Standard Brewing Co., 6 B. T. A. 980 (I927).

28. O. D. 240, I Cum. Bull. III (Igrg); A. R. R. Ir53, I-2 CuM. Bull. 92 (Ig22) ; 3 PaUL AND MERTENS, op. cit. supra note $7, \$ 25.49$.

29. I. T. I953, III-I CuMr. Bull. I39 (I924); I. T. I984, III-I CuM. Bull. I40 (I924); I. T. 2500, VIII-2 CUAr. BULl. 103 (I929).

30. 55 F. (2d) 893 (C. C. A. 2d, 1932), cert. denied, 280 U. S. 545 (1932). 
Internal Revenue assessed an additional federal income tax, thus automatically increasing the Connecticut tax. The court held, however, that this additional Connecticut tax could be deducted only in I9I8. The court, speaking by Judge Learned Hand, used the following language :

"All the facts upon which the calculation depended had been fixed before the expiration of the year I9I8. Differences could arise, and did, as to the amount of the company's income for that year, but they were due to the proper appraisal of its property, and possible disputes as to the meaning of the law. The computation was uncertain, but its basis was unchangeable; it was unknown, not unknowable on December 3I, I9I8." 31

It is probable that Judge Hand had forgotten his more realistic remark that "taxes, like other human affairs, must be determined without the gift of divination". ${ }^{32}$ To say that the liability was unknown but not unknowable is in fact to compel the taxpayer to rely upon divination, for at the close of 1918 no one but an omniscient being could have determined the actual amount of federal tax due. The practical result was that the taxpayer had to pay the additional federal tax and also the additional state tax, without any allowance being made on the former with respect to the latter. Such a result is certainly most unsatisfactory to the taxpayer and ought to be unsatisfactory to the government also.

A similar ruling was made by the Board of Tax Appeals in Haverty Furniture $C_{0 .}{ }^{33}$ where the taxpayer was compelled in 1924 to pay additional state income taxes for I92I and I922. The Board, in denying the petition of the taxpayer to be allowed to deduct such additional taxes in its federal income tax return for 1924, admitted that the taxpayer had acted in good faith but insisted that this fact "can not act as a bar to correct that which is obviously an error". 34

Three special decisions applying these principles in a rather extreme or unique manner should be briefly summarized. The first of these is the decision of the Board of Tax Appeals in the case of Great Northern Ry. ${ }^{35}$ In I 928 the taxpayer and two of its subsidiaries paid additional federal capital stock taxes assessed for I926. The Board without discussion held these payments not deductible in 1928, since the taxpayer kept books on an accrual basis. Perhaps, without some further showing, this ruling is correct enough; but the ruling with respect to Minnesota taxes is, to say the least, extreme. In I9I3 that state sued the taxpayer for additional gross receipts taxes from

31. Id. at 895 . $840(1929)$.

32. De Loss v. Comm'r, 28 F. (2d) 803,804 (C. C. A. 2d, r928), cert. denied, 279 U. S. 33. 20 B. T. A. 644 (1930).

34. Id. at 646 .

35. 30 B. T. A. 69I (1934). 
I90I-I9I2 inclusive. The case was not tried until I92I. Judgment was given in favor of the state in I924 (except for the years I9OI-IgO2), and the taxpayer appealed to the United States Supreme Court, which in I929 affirmed the state court decision. The taxpayer paid the judgment in that year. The Board held that none of the amount thus paid was deductible in r929, except what represented interest. ${ }^{36}$ The statute of limitations was, of course, a bar to any relief for the years during which the federal corporation income tax was in effect and in which the state taxes were due.

The case of Brooklyn Union Gas Co. ${ }^{37}$ involved two questions. The first of these was as to additional rates for gas; not a tax problem, of course, though quite analogous thereto. The taxpayer sought a higher rate for gas than was allowed by the existing state law, which had been previously upheld by the Supreme Court. The lower federal court decreed in favor of the taxpayer in I920 but would not permit the money to be paid over to the taxpayer unless it would put up a bond to take care of possible modification on appeal. However, the case was finally settled in I922, and the taxpayer received the additional amount which had been impounded. The Commissioner of Internal Revenue ruled that this excess constituted income for I922. The Board of Tax Appeals reversed the Commissioner, holding that it was income for the year as to which it should have been collected, even though the taxpayer had no legal right to it according to the existing state statute and had no possible power to collect it. On appeal to the Circuit Court of Appeals of the Second Circuit this decision was affirmed, ${ }^{38}$ though Judge Learned Hand, with a recurrence of his former commendable realism, ${ }^{39}$ dissented in part.

In the same case the Board of Tax Appeals held that where the taxpayer had contested state franchise tax assessments, paying only part when due, the amounts paid after the litigation was decided were deductible only when due, and not when paid. It is to be noticed that the taxpayer was in part successful for every year contested-that is, the amount claimed by the state was always reduced-but the court for most years found that more was due than had originally been paid. Yet the Board held that these amounts, which had not been properly computed either by the taxpayer or by the state itself, were, nevertheless, proper and compulsory accruals for the year for which they were ultimately found to be due. The taxpayer took no appeal to the court with respect to this tax point. But the decision of the Board, however logical, is rather absurdly unrealistic and unfair.

36. Cf. G. C. M. 9575, X-I Cuar. Bul.t. 38I (193I).

37. 22 B. T. A. 507 (I93I).

38. 62 F. (2d) 505 (C. C. A. 2d, 1933).

39. DeLoss v. Comm'r, 28 F. (2d) 803,804 (C. C. A. 2 d, Ig28). 
Finally, the decision of the Court of Claims in Acme Coal Co. v. United States ${ }^{40}$ merits brief consideration. Here again the taxpayer kept its books on an accrual basis. In I920 it sold all of its assets to an outside party, who agreed to assume all taxes of the taxpayer resulting from the sale. The taxpayer did not include any income in its 1920 return resulting from this agreement. Later, the Bureau found that the tax liability thus assumed was $\$ 66,896.03$ and added this amount to the 1920 income of the taxpayer. ${ }^{41}$ The court held that this was a proper accrual and was income for I920. It appeared, however, that as a result of a dispute, which was submitted to arbitration, the assignee of the purchaser paid only $\$ 44,639.35$, instead of the full income tax finally determined to be due. It was held that this accrual should be adjusted retroactively so as to add to the I920 income only the amount actually paid rather than the amount which the government decided to be due. To comment further upon this ruling is perhaps somewhat superfluous. Certainly the concept of a proper accrual, the amount of which is finally determined by the government several years later and then is reduced because of an adjustment between the parties to an agreement, is one which seems neither sensible or even understandable.

It may be conceded that the propriety of a practical rather than a theoretical adjustment as to tax deductions is not quite so plain with respect to losses. ${ }^{42}$ It is often difficult to determine exactly when a loss takes place, and this difficulty is at least much less frequently presented with respect to taxation. Nevertheless, it is believed that it has been shown that retroactive adjustments for tax deductions are often even theoretically difficult to justify. But the practical injustices, especially with regard to differences in tax rates and the statute of limitations, are far more serious. The authorities which have been discussed would seem to ignore this consideration altogether. However, it is not ignored in all cases; and this aspect of the authorities must now be considered.

The only authority which directly considers the problem of the difference in tax rates is Inland Products Company v. Blair, ${ }^{43}$ already discussed. Here the court states as one of its reasons for declining to permit the error to be corrected by treating the refund as income for the year in which it was made that federal income tax rates were declining and that the government would, therefore, receive less revenue if retroactive correction of the error were not insisted on. But the argument seems to be a boomerang when, as at present, income tax rates are going up. The truth appears to be that difference in tax rates is of itself no argument for either solution. Whichever way

40. 44 F. (2d) 95 (Ct. Cl. I930).

4I. United States v. Boston \& Maine R. R., 279 U. S. 732 (I929).

42. Lucas v. American Code Co., 280 U. S. 445 (I930) ; see Brown, loc. cit. supra note 3.

43. 3I F. (2d) 867 (C. C. A. 4th, 1929), $a f^{\prime} g$, Io B. T. A. 235 (I928). 
the tax rates are tending, a retroactive correction is at least theoretically desirable as resulting in the exact tax liability which should be paid.

But when we come to the effect of the statute of limitations, the problem is not so simple. Here the attempt to force both the government and the taxpayer back to the year in which the error was originally made is likely to mean a loss for one side or the other. Either the government will be unable to collect additional income taxes due for the past year, or the taxpayer will not be able to enforce his right to a refund for such taxes overpaid for that year. Where the taxpayer has acted in bad faith, the government, of course, will not be barred, and where the error, though bona fide, is serious and inexcusable, there is perhaps no serious injustice in thus barring the taxpayer. But the question remains whether the authorities countenance the making of any adjustment with respect to the statute of limitations under any circumstances.

In some cases, they have explicitly declined to do so. Thus the Solicitor of Internal Revenue has said in one of his rulings:

"In most instances when a taxpayer has failed to accrue and deduct a liability in one year and is not allowed to deduct it in a subsequent year when paid, he is permitted to amend the return of the year in which the deduction should have been taken and thus obtain relief. In the instant case taxes could not be accrued and deducted under the Act of August 5, 1909, even if the circumstances were such that this taxpayer could file amended returns for the years 1909 to I9I2, inclusive. It thus results that the additional taxes paid in I920 can not be deducted in any year and the usual relief can not be afforded this taxpayer." 44

Apparently, so far as the government is concerned, the Bureau considers it very fortunate if the taxpayer is precluded by the statute of limitations from recovering excess income taxes paid by him in the past years through his own mistake, however excusable; and the Board of Tax Appeals seems to agree with this conclusion. ${ }^{45}$ The obvious injustice of this position does not comport very well with the occasional judicial eulogies of governmental morality. ${ }^{46}$

Yet there is at least one decision of the Board of Tax Appeals which seems to take a position favorable to the taxpayer. This is the case of Charles $F$. Fazecett. ${ }^{47}$ Here the taxpayer, a resident of Wisconsin, included in his state income tax return his wife's income, as required by the laws of that state. Subsequently the United States Supreme Court held this pro-

44. S. M. 2692, IV-I CuM. BuLl. IIg (1925).

45. American Cigar Co., 2I B. T. A. 464 (I930), aff'd, 66 F. (2d) 425 (C. C. A. 2 d, I933), cert. denied, 290 U. S. 699 (I933).

46. Inland Products Co. v. Blair, 3I F. (2d) 867 (C. C. A. 4th, I929), aff'g, ro B. T. A. 235 (1928).

47. 30 B. T. A. 908 (1934). 
vision of the Wisconsin statute unconstitutional. ${ }^{48}$ The Commissioner then disallowed as a deduction that part of the state income tax attributable to the income of the wife, as illegally collected. ${ }^{49}$ The taxpayer appealed to the Board, which reversed the Commissioner. The reasoning of the Board is not unnaturally extremely abstruse and difficult to follow. However, it put much reliance upon the fact that the statute of limitations had run upon the refund of the federal income tax before the Supreme Court decision invalidating the state tax was rendered. As a theoretical matter, and under the rulings previously cited, this consideration is, of course, wholly immaterial; but the gross injustice of the result was sufficient to induce the Board to change the ruling in this particular case. It is submitted that this decision is far more just and reasonable than would have been obtained by adherence to the precedents or to mere logic.

When it comes to the government, rather than the taxpayer, being barred by the statute of limitations, the rulings are much more liberal. Thus, as we have seen, the Bureau has ruled ${ }^{50}$ that a deduction of a tax later declared unconstitutional is wholly void and can not be corrected by allowing it to stand and treating the refund as income when received. The Bureau agreed that the latter method is easier, but insisted that it was not a legal method, to leave the matter in abeyance "except where it is necessary to protect the government's intrests due to the running of the statute of limitations against assessment." But why the difference?

So, in Inland Products Co. v. Blair ${ }^{51}$ the court considered the same matter and said:

"It is said that the conclusion at which we have arrived will result in injustice to the government in cases where taxes are held unconstitutional and refunded for that reason, and where the right to readjust income tax returns has been barred by the statute. It is urged that in such cases if the refund is not treated as income of the current year, it will escape taxation. Such a case is not before us, and we need not decide it. We will say in passing, however, that in making the refund in such cases, which would be made voluntarily, it would seem that the government might be able to protect itself with respect to the additional income tax due by the taxpayer." 52

Thus the court makes the rather naive suggestion that the government may simply disregard the statute of limitations whenever it injures it, a suggestion which is obviously inapplicable but does show a recognition of the

48. Hoeper v. Tax Commission of Wisconsin, 284 U. S. 206 (I93I).

49. I. T. 274I, XII-2 CuM. BuLL. 48 (I933).

50. I. T. 2578, X-I CUM. Bull. II9 (I93I).

5I. 3r F. (2d) 867 (C. C. A. 4th, I929), aff'g, ro B. T. A. 235 (I928).

52. Id. at 869 . 
injustice of a wooden application of the theoretical rule, at least when the government is hurt.

A rather recent decision of the Board of Tax Appeals, Houbigant, Inc., ${ }^{53}$ is very important on this point. Here the taxpayer had deducted customs duties paid prior to I930 as part of the cost of goods sold. In I93 I a considerable amount was refunded by the government because part of the customs duties had been illegally exacted, due to a misconstruction of the statute. The Board held that this refund was income for I93I-directly contrary, it will be noted, to practically all of the rulings already discussed. The reason for this very surprising decision was that the government was barred for most of the years in question from exacting any further income tax, by reason of the statute of limitations. The Board, therefore, thought that the only fair result was to treat the refund as income in the year in which paid. Again the ruling seems realistic and fair; but what is fair for the government is fair for the taxpayer. In other words, if the authorities are tending toward the practical adjustment of erroneous tax deductions for the protection of the government, they are doing well; but justice and plain honesty require that the taxpayer be treated likewise, unless he has acted fraudulently or with such complete disregard of ordinary requirements of fairness in making his returns that the forfeiture of an overpayment of income tax is justified.

Moreover, there are authorities which do in fact, though usually not avowedly, tend toward a practical application of this problem of tax deductions for income tax purposes, without regard to which party is involved. For instance, the Bureau has ruled that where customs duties were properly collected but are refunded because of a later eventuality, the deduction in the previous year will stand, and the refund will constitute income for the year in which it was received. ${ }^{54}$ The following language is made use of on this point:

"It sometimes happens that duties or taxes are legally or properly collected, but by reason of some subsequent event are refunded. An example of this type of case is the refund under the drawback provisions of the law where the importer pays the customs duties but later secures a refund by showing that the goods imported on which the duties were paid have gone into a manufactured article which was later exported. In such a case the collection of the customs duties was entirely legal and the refund thereof did not constitute the correction of a mistake because no mistake had been made. Therefore, legal and proper collections of customs duties and taxes should be distinguished from those illegally or improperly made. Refunds of customs duties or taxes, the collection 
of which was legally or properly made, should be treated as income for the year in which refunded." 55

Similarly, where an additional tax is imposed retroactively, the deduction for the previous year can include only the tax due in that year. ${ }^{58}$ The theory is that a tax payable for a certain year but imposed only by a law passed subsequent to that year is not legally or practically due and is, therefore, not a proper accrual. The same principle has been applied to the Federal Revenue Act of I9r8, so far as that year was concerned, since the act was not passed until February, 1919. ${ }^{57}$ On the other hand, if an excess tax is retroactively reduced, on the same reasoning the deduction remains and the subsequent refund constitutes taxable income when received.58

It can not be denied that such a situation is distinguishable from the more usual one where an error is made with respect to a tax already imposed by law. If, however, it be conceded that the accrual basis of accounting is to be applied from a practical rather than a theoretical standpoint, the difference is not very great. If no one can foresee a retroactive change of tax statutes, neither can one really be expected to anticipate the many difficult and technical rulings which are going to be made at some time in the future with respect to the application of existing tax laws. In either case, it would seem fairer to let the previous errors stand and correct them in the subsequent year, assuming, of course, that the taxpayer acted honestly and with a reasonable degree of care. Even if he did not, the government should, of course, not be prejudiced through the application of the statute of limitations, though the taxpayer may well be thus penalized.

And even where there is not such technical legal justification for a practical construction of the deduction for taxes, there are rulings which apply it, at least to some extent. For example, the Bureau has been confronted with a rather peculiar situation under the tax laws of Wisconsin. That state allows an offset against income tax liability for one year of personal property taxes paid the next year, the amount of which is not determinable until nearly the end of the next year. Under this peculiar set-up, the Bureau has ruled that since the amount of income tax actually due is not determinable until the next year, no deduction for income taxes can be made until that next year, even by taxpayers on an accrual basis. ${ }^{59}$ The idea is that such an indefinite amount is not a proper accrual. Here, too, we have an application of

55. Id, at 35 .

56. O. D. 387,2 CuM. Bulr. II6 (I920); O. D. III8, 5 Cun. Buld. I33 (I92I); Ed Shuster \& Co. v. Williams, 283 Fed. II5 (C. C. A. 7th, I922); James B. Coombs, I7 B. T. A. 279 ( 1929 ).

57. Norwich \& Worcester R. R. Co., 2 B. T. A. 215 (1925), aff'd, I6 F. (2d) 944 (D. Mass. I926).

58. G. C. M. 6075, VIII-I Cum. Bulx. 76 (1929).

59. I. T. I272, I-I Cun. Bull. I23 (I922); A. R. R. 3656, II-2 Cun. Bull. 48 (I923). 
the practical test for handling tax deductions, though, strictly speaking, the amount of the personal property tax for the next year is not merely "unknown" but "unknowable". ${ }^{60}$ It must be noted, however, that these rulings of the Bureau have been upset by the Board of Tax Appeals, ${ }^{61}$ though apparently on the ground that the Wisconsin rulings showed that this peculiar method was simply a backhanded way of abolishing the personal property $\operatorname{tax}$.

Furthermore, a ruling of the General Counsel of the Bureau of Internal Revenue with regard to the accrual of interest on a deficiency of tax is worth noticing. ${ }^{62}$ It was stated that such interest should be accrued and collected in one year in which the liability is finally determined, and not spread over the time since the tax was due. The General Counsel took this position mainly on the ground that the amount of such interest was wholly unascertainable until the amount of the additional tax was determined, though it would seem that on the orthodox view, the additional tax liability had already been incurred and should have been known, and the accruing interest thereon is a matter of simple mathematical computation.

However, the ruling recognizes the importance of the practical aspect, particularly with reference to the administrative problems. The language on this point is very interesting:

"Furthermore, the accrual of the deduction ratably from the time the tax was due until final satisfaction appears to be subject to strong administrative objections. Where the deficiency is disputed, in whole or in part, by the taxpayer the Income Tax Unit is faced with the practical difficulty of not knowing how much of a deduction on account of interest to allow in its audit of returns for subsequent years. Where the dispute is prolonged beyond two years, in cases carried to the Board of Tax Appeals, the allowance of interest on a deficiency subsequently determined not to exist, would not appear to be in harmony with good accounting practice or sound tax administration. For example: Suppose in I925 a deficiency of $\$ 1,000,000$ for I92I was asserted in a 60day letter and the taxpayer filed a petition before the Board of Tax Appeals. If the Board determined in I930 that no deficiency existed and the unit had in the meantime allowed as a deduction the interest on $\$ 1,000,000$ for the years I922 to 1930 , inclusive, it would then find itself in the position of having allowed a deduction for an item which never existed and being unable to make proper adjustment for all or part of the years due to the statute of limitations. If, on the other hand, the accrual is postponed until the year in which the dispute as to liability is terminated and the actual liability is determined or agreed upon, no such problem would arise.

6o. Compare statement of Judge Learned Hand, supra p. 394.

6r. Ira L. Henry Co., 9 B. T. A. 540 (1927); Christensen Machine Co., 18 B. T. A. 256 (1929). But of. Shurtleff Ice Cream Co., I B. T. A. I168 (1925); Twin Disc Clutch Co., 2 B. T. A. I327 (I925).

62. G. C. M. 9575, X-I Cun. Bull. 38I (I93I). 
Accordingly, it is the opinion of this office that the interest on deficiencies in tax should be accrued in the year in which the liability for the deficiency is finally determined, either by an agreement, final order, or judgment." 63

This is certainly an admission that practical considerations, especially in connection with the statute of limitations, should be considered, at least where the government would otherwise be injured.

Finally, the rather recent ruling of the Board of Tax Appeals in Central United National Bank ${ }^{64}$ should be considered. Here the taxpayer, which reported for its income tax on the accrual basis, accrued on its books personal taxes due to the state of Ohio for 1928, I929, and 1930. However, such taxes were not paid, on account of litigation involving their validity. In 1932 the taxpayer paid its Ohio taxes for these years, but at a much lower rate than the amount accrued, the amount paid being fixed through a compromise with the state authorities, even though the validity of the Ohio tax was finally upheld in full. The amount thus saved was reported by the taxpayer as income for I932. The Board (though with a very vigorous dissent, concurred in by three members) upheld this method of treating the transaction. The majority opinion of the Board uses the following language:

"The facts do not support the respondent's position. As to each year, the petitioner entered on its books correct accruals of the personal taxes which the taxing authorities of Cuyahoga County had determined it was compelled to pay. All of the events necessary to fix the amount of the tax and the liability of the taxpayer to pay it had occurred within the respective taxable years. United States v. Anderson, 269 U. S. 422. Subsequent to December $3 \mathrm{I}$ of each year, it attacked the assessment of such taxes as being illegally discriminatory. It did not question the correctness of the amount assessed or the valuation employed. $C f$. Inland Products Co. v. Blair, 3I Fed. (2d) 867; Brooklyn Union Gas Co., 22 B. T. A. 507 . Thus, it was not a matter of correcting an error, but a denial of the petitioner's liability for any tax such as was imposed." 65

It would seem, however, that since the amounts accrued turned out to be too much (whether for legal or other reasons), the orthodox theory would have required the taxpayer to reduce its deductions for the years for which payments were made (thus increasing the income tax liability for those years) and to exclude the difference as income for the year in which the compromise was made. Indeed, this is the very contention of the dissenting opinion. The opinion of the majority of the Board is thus actually, though

63. Id. at 383 .

64. 33 B. T. A. 588 (1935).

65. Id. at $59 \mathrm{I}$. 
perhaps not avowedly, a recognition of the practical method of correcting errors in tax deductions.

The clear weight of authority in the Bureau, in the Board of Tax Appeals, and in the courts is nevertheless in favor of the orthodox view. This is, in effect, that any error with respect to tax deductions must for income tax purposes be corrected for the year in which the error was made, without affecting the taxable income of the taxpayer for the year in which the correction was made. There is some tendency in a few of the decisions toward the opposite treatment-that is, letting the error stand for the year in which it was made and correcting it by adding to or deducting from the taxable income of the taxpayer in the year in which the correction was made. This tendency appears quite frequently where the statute of limitations in the income tax law would otherwise affect the rights of the parties, or at least of the government; but it is not entirely confined to such cases.

It must be conceded that such a purely practical method of handling tax deductions can not be so universally defended as in the case of treatment of deductions for losses. If there is fraud on the part of the taxpayer, the government will, of course, not be affected by the statute of limitations; but conversely, the taxpayer should get no benefit from his fraud. If, under such circumstances, he is debarred from a refund to which he would otherwise be entitled (though this would rarely happen) no one need be disturbed.

If the taxpayer acts in good faith but is seriously negligent or intentionally violates a tax law (whether the income tax law or the law imposing the tax which he desires to deduct), it is again a case where he is perhaps hardly in a position to urge that he should be entitled to correct his error in a subsequent year in order to get the benefit of an overpayment of income taxes in the previous year, recovery of which is barred by the statute of limitations. Even in this case, however, the government should not be barred by the statute of limitations, and the tendency is to so hold. ${ }^{66}$

Where, however, the error is a wholly excusable one on the part of the taxpayer, and even more when the error is due to the human failure or inability to anticipate and correctly interpret future rulings of the tax authorities, it is submitted that the practical solution, of allowing the error to stand and correcting it by additional assessment or refund of income taxes for the year in which the correction was made, is generally the desirable one. Certainly the taxpayer should not be permitted to correct even an excusable error in a previous year, by which he underpaid his federal income taxes, if the collection of the additional tax is barred by the statute of limitations. But it is just as unfair for the government to force the taxpayer to correct such an error in such previous year by which he overpaid his income taxes, if the

66. See authorities cited supra notes 50-53. 
taxpayer can not obtain a refund of such overpayment by reason of the statute of limitations. Where the statute of limitations is not involved, it may be just as well to require the retroactive correction of the mistake, as this is technically bringing about the exact tax liability that should have been paid. But even here it seems useless, from the standpoint either of the taxpayer or the government, to insist upon such elaborate recalculations, unless the difference in the amount of income tax involved is really substantial.

It is believed, therefore, that the rulings and decisions which have approved the practical solution should be extended, and that this method of correcting any errors with respect to tax deductions should be invariably permitted and required, unless it is affirmatively shown to work out in the particular case with substantial unfairness either to the taxpayer or the government. 